DOI: $10.2478 / \mathrm{v} 10047-011-0025-6$

\title{
AFTER-IMAGES IN CHROMOLUMINANT SPACE
}

\author{
S. Fomins ${ }^{1}, \mathrm{U}$. Atvars ${ }^{2}$ \\ ${ }^{1}$ Institute of Solid State Physics, University of Latvia, \\ 8 Kengaraga Str., LV-1063, Riga, LATVIA \\ ${ }^{2}$ Optometry and Vision Science Department, University of Latvia, \\ 8 Kengaraga Str., LV-1063, Riga, LATVIA \\ e-mail: sergejs.fomins@lu.lv
}

\begin{abstract}
Prolonged viewing of colored surfaces produces the sensation of after-image, which results in a complementary color to the one physically presented. Retinal pigment bleaching along with neural factors is supposed to be the basis of afterimages. We have developed a computer-aided technique for matching the after-image complementary hues, in which the stimulus is composed of twelve circularly placed colored patches. One of the patches disappears in the clockwise direction for $300 \mathrm{~ms}$, while others are static. The perceived after-image color is matched in the central patch. Colors of the stimuli are defined in the DKL opponent color modulation space for isoluminance conditions. In the experiment, no significant changes in brightness were identified for after-image complementaries. We observed elongate saturation along the diagonal axis (close to $135^{\circ}$ ). To fit the saturations of complementary colors the sum of sine functions is proposed.
\end{abstract}

Key words: after-image, opponent modulation space, complementary hues.

\section{INTRODUCTION}

Human color sensation stems from the light absorbed by long-, medium-, and short-wavelength (L, M, and S) sensitive cone receptors in the retina. This physiological aspect provides basis for the trichromatic theory of color perception, stating that any color sensation could be produced and matched by additive mixture of three basic colors. However, after the retinal transformation of light into a neural electrical impulse the signal is transformed in the post-receptoral pathways into three opponent type channels, separately processing luminance, red-green, and blue-yellow information [1]. The initial stages of color processing expressed by the trichromatic theory are hard to challenge, but it became obvious that those could not fully explain visual phenomena. Ewald Hering introduced the concept of opponent colors which are result of the nervous system processing of retinal impulses [2].

Quantitative data for the color opponency was provided by Hurvich and Jameson (1957) [3]. Using hue cancellation paradigms, the psychophysical color opponent channels were isolated. Therefore, by adjusting the amount of blue or yellow and red or green, any sample wavelength can be matched.

It has long been observed that after an observer fixates on the colored patch for a more or less extended time he/she sees an illusory complementary color - an after-image. Several stages of the after-images have been extensively studied. In 
the first stage (named Hering's after-image), observing a brightly colored light the subject sees a positive (of the same color) after-image of extremely short duration. The second - most recognized and prominent - stage is a negative after-image of complementary hue (named after Purkinje) $[4,5]$.

An extensive study of the complementary hues of Purkinje's after-images was made about sixty years ago [6]. Technically, the experiment was carried out based on the rotating disk colorimetry, with test colors chosen from the Munsell color system. It was found that most of the complementaries experience hue shifts from linear, with a change in saturation. There were two axes of green-yellow to purple and red to blue-green, which showed a consistent hue over the range of saturations.

The color science has made a huge step ahead since the days of Wilson and Brocklebank [6], offering new concepts of the color data analysis and representation based on physiological investigations [7, 8]. The MacLeod and Boynton cone chromaticity space [9] allows analyzing the chromatic data in cone excitation units, which rivals the classical CIE system related to color matching but not retinal pigment excitation and contrast mechanisms. An extended version of physiological analysis is brought by a derivative of MacLeod-Boynton's diagram - an opponent modulation color space (the latter named by the initials of authors - DKL - and incorporates two basic principles of retinal processing $[7,10])$. In the DKL space, the retinal pigment excitations are presented in a contrast (or relative) form. Second, there are three relatively divided processing channels, with a red-green channel corresponding to $0-180^{\circ}$ and a blue-yellow one corresponding to $90-270^{\circ}$ on the hue circle [10].

In our study we have obtained the complementary hues of after-images for stimuli in the opponent modulation color space. We have also tried to identify the mechanisms of saturation of color after-image in the context of cardinal directions of the DKL color space.

\section{EXPERIMENTAL}

In the experiment, two male and three female subjects participated, with the average age of $24.2 \pm 2.3$ years. All participants of the experiment had no color vision deficiencies and the corrected eye sight.

The color after-image evaluation method was set up with stimuli based on the "Lilac Chaser" principle of visual illusions [11]. The stimuli consisted of 12 circular patches arranged in a circular format, creating a clockwise combination (Fig. 1). The background of stimuli is chosen gray $(\mathrm{RGB}=128,128,128)$, with CIE coordinates $x=0.283, y=0.334$ and the luminance value of $25 \mathrm{~cd} / \mathrm{m}^{2}$. During the experiment, 11 of the 12 circles were presented, and one of the patches disappeared in the clockwise directions for $400 \mathrm{~ms}$. The 11 test patches presented were of the same color (coded in the HSL color space) and 16 hues chosen for the experiment. Luminance values of all the 16 colors were matched to the background luminance and measured with a Konica Minolta CS-100A chroma- meter. Figure $1 a, b$ shows the arrangement of the test stimulus colors in the DKL color space and the CIE $x, y$ chromaticity diagram. The chromaticity coordinates were scaled to match the monitor gamut, which resulted in the compression of the L-M axis and elongation of the stimulus coordinates along the $(\mathrm{L}+\mathrm{M})-\mathrm{S}$ cardinal axis. 
A prolonged viewing of the stimuli produced the sensation of a rotating patch of complementary color. In the center of experimental stimuli the adjustment patch was placed. Two fixation squares were given besides the point of central symmetry. The rationale for using two fixation points comes from our experience in the change of color perception of central area after prolonged matching. The gaze is switched between two fixation squares which help to move the matching patch as well as stimuli to a different retinal location. The angular size of the chromatic patch is $0.83^{\circ}$, and the distance from the fixation square to the stimulus is $1.66^{\circ}$. The distance from the outer circle to the central test circle is $3.32^{\circ}$.

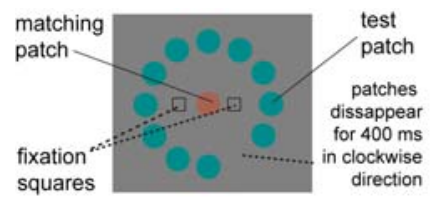

a

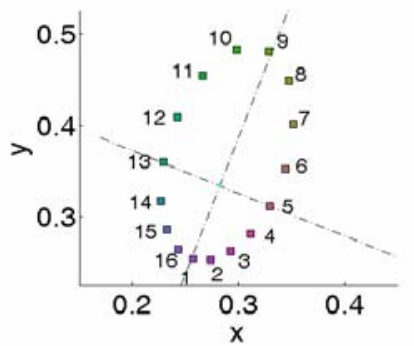

$\mathrm{b}$

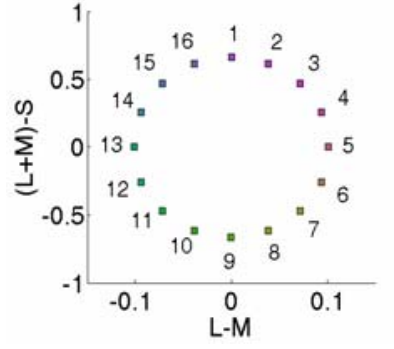

C

Fig. 1.

(a) Experimental stimuli with 11 test chromatic disks and the matching patch presented on a gray background. Color attributes of the test patch in the center are adjusted using keyboard.

(b) Chromaticity coordinates of test stimuli in CIE $x, y$ diagram.

(c) Test stimulus coordinates in the DKL opponent modulation color space. No 1, 9 correspond to the blue-yellow mechanism. No 5, 13 on the horizontal cardinal axis correspond to the opponent redgreen mechanism.

Three different color spaces are used to represent stimuli. For the afterimage matching procedure, the Hue Lightness Saturation (HLS) model is used, as it is most intuitive and easily controllable by keyboard. The HLS data are transformed into RGB digital counts, which are related to the physical spectral characterization of the PC monitor. Test stimuli are chosen in the DKL color space according to the chosen gray background chromaticity coordinates, and are easily convertible to the MacLeod-Boynton cone excitation. Mathematic transformations are distilled from original papers on the display colorimetry and chromaticity spaces $[10,12-14]$.

\section{RESULTS AND ANALYSIS}

In Fig. $2 a$, the average values of the perceived after-image colors and their standard deviations are depicted. The error bars represent the standard deviations in both axes, while Fig. $2 b$ shows the luminance variation of complementary hues. The luminance set for background and stimuli is $25 \mathrm{~cd} / \mathrm{m}^{2}$. The matched after- 
images for the red, yellow and green stimuli (No 5-12) (blue and violet) are slightly over the $25 \mathrm{~cd} / \mathrm{m}^{2}$ level. The results show only minor luminance variations of after-images. Blue and red stimuli (No 1, 2, 13-16) produce less luminous aftereffects. However, the variations in luminance are not significant.

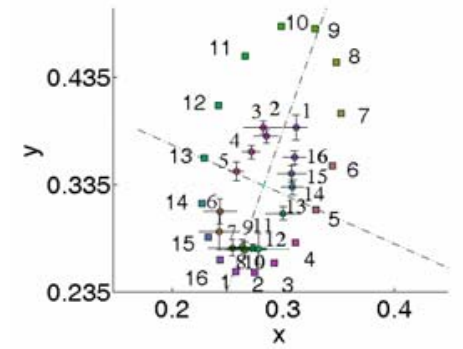

$\mathrm{a}$

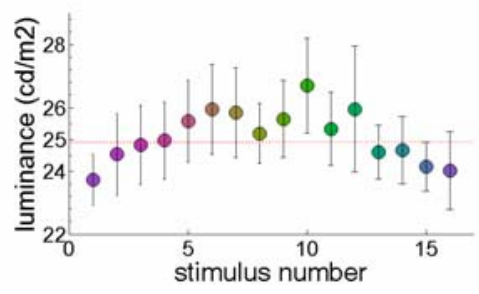

b

Fig. 2.

(a) Test stimulus colors (squares) and matched after-image colors (circles) in the CIE $x, y$. The error bars indicate standard deviations. Dot-dashed lines going through the neutral point $(0.283 ; 0.334)$ are the cardinal mechanism directions identified from DKL color space.

(b) Luminance variations of matched after-images. Test stimuli number on the $x$-axis and evaluated luminance of the corresponding after-image on the $y$-axis.

The saturation values for each hue of the after-images can be analyzed in the DKL color space (Fig. $3 a$ ). The most saturated after-images are produced by the stimuli of yellow (No 6-8) and green (No 9-12) hues; after-images of lower saturation - by pink (No 2, 3, 4) and blue (No 15, 16). The contrast in each of the cardinal mechanisms was calculated for test stimuli and after-image (Fig. 3b). The most identical color contrast is perceived for after-images produced by stimuli No 5-7 and No 11-13. Saturation compression is observed for lime and green test colors (aligned on the lime-violet cardinal axis). Even greater compression is found for the blue and violet stimuli (No 1, 2, 15, 16) producing yellow and lime afterimages.

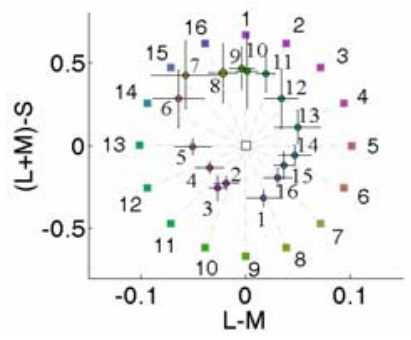

a

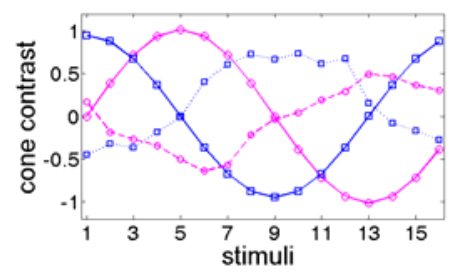

b

Fig. 3.

(a) Test colors (squares) and after-images (circles) in the DKL color space.

(b) Normalized cone contrast in cardinal mechanisms. Solid lines - test stimuli in $0-180^{\circ}$ (squares) and $90-270^{\circ}$ (circles). Dashed lines - produced complementary hues of after-images.

One of the benefits of opponent modulation space is contrast detection along the cardinal mechanisms. On the basis of our findings we propose a model of the after-image saturation prediction. For this task the normalized contrast slopes in 
each of the cardinal mechanisms were fitted by sinusoidal functions. In the first attempt we tried to fit the contrast data by a single sinusoidal function:

$$
F_{1}(x)=a_{1} \sin \left(b_{1} x+c_{1}\right),
$$

where $a_{1}$ is the function amplitude,

$b_{1}$ is the frequency coefficient,

$c_{1}$ is the function phase.

Despite the fact that the fitted function provided high $\mathrm{R}^{2}$ values (over 0.9), the sum of both cardinal mechanisms on the DKL isoluminant plane showed a disputable fit to the average data. For this reason, we turned to a more complex function of triple sine components. Coefficients $a_{1,2,3}, b_{1,2,3}$, and $c_{1,2,3}$ in the relevant equation describe the character of each of the sine functions:

$$
F_{2}(x)=a_{1} \sin \left(b_{1} x+c_{1}\right)+a_{2} \sin \left(b_{2} x+c_{2}\right)+a_{3} \sin \left(b_{3} x+c_{3}\right)
$$

Using Eq. (2), the goodness of fit in the R-square value was 0.986 for the red-green channel, and 0.995 for the blue-yellow cardinal axis. We have employed this model to predict the saturation data of the obtained complementary hues. Figure $4 a$ shows the fitted functions in the cone contrast for both cardinal axes. To project a fit on the DKL, two dimensional isoluminant plane models for each of the channels were summed to form a circle function. Figure $4 b$ represents the saturation fits in the DKL color space. The saturation values show good agreement with the experimental data. The modelled hue position varies to an extent, but basically fits into the dispersion areas.

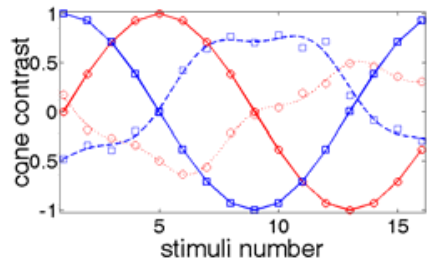

a

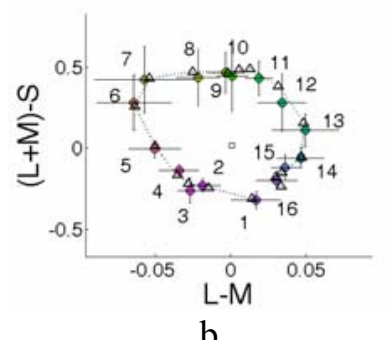

$\mathrm{b}$

Fig. 4.

(a) Normalized contrast along cardinal axes and Eq. (2) fitted functions. Test stimuli contrast changes along the blue-yellow axis (squares), and red-green axis (circles). The after-image data are fitted with a triple sine function (Eq. 2); fits are depicted with dashed lines.

(b) Sum of cardinal channels fitted on the DKL space isoluminant plane. Circles: the average value of after-image; error bars indicate the standard deviation. Dotted lines: predicted saturation values for our stimuli. Triangle symbols: predicted hue values.

\section{DISCUSSION}

Our results provide valuable information on the mechanisms of after-images in the opponent modulation color space. We have used a trichromatic visual display to produce the after-images (in contrast to the previous thorough works on the complementary hues [6]). The distributions of after-images in the CIE $x, y$ diagram are similar to the data of Wilson et al. [6], showing smallest changes from linearity along the cardinal axes (No 5,13; No 1,9). The shape of responses in the DKL color space shows that the yellow and green after-images produced by blue 
and violet stimuli are of lower saturations, while after-images for green and yellow stimuli are of highest saturation. Our findings are similar to the trends observed in the color-contrast experiments with monochromatic sinusoidal gratings presented on a neutral background [15]. Also, our results show greater saturations for blue complementary hue`s degrees than those in DKL space.

\section{CONCLUSIONS}

Complementary hues of after-images have been identified for the stimuli determined by the DKL isoluminant plane. Saturation value compression for yellow after-images was produced by blue stimuli (No 7, 9; DKL hue angle $\sim 135^{\circ}$ ). The luminance of complementary hues is slightly variable around the mean stimulus luminance, with lower values for pink and violet stimuli, and higher values of luminance produced by yellow and green stimuli. The data are fitted by the sum of triple sinusoidal functions and provide a simple model for prediction of saturation. Our results resemble those obtained in experiments [15] on the salience of chromatic contrast stimuli in the chromoluminance space for sinusoidal gratings.

\section{REFERENCES}

1. Shevell, S.K. (2003). The Science of Color (2 $2^{\text {nd }}$ ed-n). Oxford (UK): Elsevier.

2. Hering, E. (1964). Outlines of a Theory of the Light Sense. Cambridge (Mass): Harvard University Press.

3. Hurvich, L.M., \& Jameson, D. (1957). An opponent-process theory of color vision. Psychological Review, 64 (6), 384-404.

4. Judd, D.B. (1927). A quantitative investigation of the Purkinje after-image. The American Journal of Psychology, 38 (4), 507-533.

5. Frehafer, M.K. (1929). Preliminary note on after-images from stimuli of low saturation and short duration. The American Journal of Psychology, 41 (2), 277-283.

6. Wilson, M.H., \& Brocklebank, R.W. (1955). Complementary hues of after-images. Journal of the Optical Society of America, 45, 293-299.

7. Derrington, A.M., Krauskopf, J., \& Lennie, P. (1984). Chromatic mechanisms in lateral geniculate nucleus of macaque. Journal of Physiology, 357, 241-265.

8. Krauskopf, J., Williams, D.R., \& Heeley, D.W. (1982). Cardinal directions of color space. Vision Research, 22 (9), 1123-1131.

9. MacLeod, D.I.A., \& Boynton, R.M. (1979). Chromaticity diagram showing cone excitation by stimuli of equal luminance. Journal of the Optical Society of America, 69, 1183-1186.

10. Brainard, D.H. (1996). Cone contrast and opponent modulation color spaces. Human Color Vision (eds: Kaiser, P.K., \& Boynton, R.M.), Washington, D.C.: Optical Society of America, pp. 563-579.

11. Blue, R.C. (2005). A visual yet non-optical subjective intonation. Electroneurobiología. 13 (3), 299-300.

12. Smith, V.C., \& Pokorny, J. (1996). The design and use of a cone chromaticity space: a tutorial. Color Research and Application, 21, 375-383.

13. Golz, J., \& MacLeod, D.I.A. (2003). Colorimetry for CRT displays. Journal of the Optical Society of America, 20, 769-781.

14. Brainard, D. H., \& Stockman, A. (2010). Colorimetry. OSA Handbook of Optics $\left(3^{\text {rd }}\right.$ ed-n; ed-r: M. Bass). New York: McGraw-Hill. 10.1-10.56.

15. Switkes, E. (2008). Contrast salience across three-dimensional chromoluminance space. Vision Research, 48, 1812-1819. 


\title{
PĒCATTĒLU NOTEIKŠANA OPONENTĀS MODULĀCIJAS KRĀSU TELPĀ
}

\author{
S. Fomins, U. Atvars
}

Kopsavilkums

Ilgstoša krāsainu objektu novērošana noved pie pēcefekta sajūtas, kad novērota objekta vietā parādās papildkrāsas pēcattēls [1]. Par pamatu tam uzskata divus procesus. Pirmkārt, tīklenes pigmentu izbalēšanu un, otrkārt, aiz tīklenes notiekošus neirālos procesus [2-4]. Lai noteiktu pēcattēlu krāsu un piesātinājumu, tiek piedāvāta datorizēta metode. Stimuls pēcattēlu noteikšanai sastāv no divpadsmit riṇkī izvietotiem krāsainiem apļiem uz pelēka fona ar spožumu $25 \mathrm{~cd} / \mathrm{m}^{2}$. Eksperimenta laikā ik pēc katrām $300 \mathrm{~ms}$ viens no apliem izzūd pulksteņrādītāja virzienā, kamēr pārējie tiek demonstrēti. Stimula novērošana noved pie papildkrāsā nokrāsota pēcattēla uztveres izzūdošā ap̣̣a vietā. Lai piemeklētu pēcattēla krāsu, piesātinājumu un spožumu, stimula centrā ir ievietots piekārtošanas aplīis, kura krāsu parametrus maina ar tastatūras palīdzību. Testa krāsas ir izvēlētas oponentās modulācijas krāsu telpā (DKL). Rezultāti uzrāda nenozīmīgas pēcattēla gaišuma izmaiṇas. Dzeltenas krāsas stimuliem (Nr. 7,9) ir noteikts pēcattēlu piesātinājuma palielinājums salīdzinājumā ar citas krāsas stimuliem. Piedāvāts izmantot trīskāršo sinusa funkciju pēcattēlu piesātinājuma aprakstīšanai. 